\title{
Use of carbohydrases in corn-soybean meal based grower-finisher pig diets
}

\author{
Sung Woo KIM ${ }^{\mathrm{a}, \mathrm{c} *}$, Jin H. ZHANG ${ }^{\mathrm{b}}$, Kevin T. SolTWEDEL ${ }^{\mathrm{b}}$, \\ Darrell A. KNABE ${ }^{\mathrm{c}}$ \\ ${ }^{\text {a }}$ Department of Animal and Food Sciences, Texas Tech University, USA \\ ${ }^{\mathrm{b}}$ Department of Animal Sciences, University of Illinois, USA \\ ${ }^{\mathrm{c}}$ Department of Animal Science, Texas A\&M University, USA
}

(Received 2 August 2005 - Accepted 8 September 2006)

\begin{abstract}
Four experiments were conducted to determine the effects of carbohydrase (CS) supplements in pig diets on ileal digestibility and ammonia emission. The CS used in this study is composed of the enzymes obtained from Aspergillus niger and Aspergillus oryzae during their fermentation process. The major active enzymes were $\alpha$-1,6-galactosidase, $\beta$-1,4-mannanase, and $\beta$-1,4-mannosidase that target flatulence producing compounds in soybean meals. In experience 1 (Exp. 1), 8 cannulated barrows $(93.9 \pm 2.0 \mathrm{~kg})$ were fed diets with CS supplementation $(0.00,0.05$ and $0.10 \%$ ) in order to measure ileal nutrient digestibility. Ileal digestibilities of lysine, threonine, and tryptophan were improved $(P<0.05)$ with CS supplements at $0.05 \%$ and $0.10 \%$, whereas digestibility of methionine and branched-chain amino acids did not improve. Supplementing $0.05 \%$ CS increased $(P<0.05)$ apparent ileal energy digestibility. In experience 2 (Exp. 2), 100 pigs $(24.1 \pm 0.6 \mathrm{~kg})$ were fed either a control diet $(3278$ Mcal ME per kg diet) or a low-energy diet (3 $109 \mathrm{Mcal}$ ME per kg diet) with $0.05 \% \mathrm{CS}$ for 4 -wk. No differences $(P>0.05)$ were observed for ADG, feed intake, and gain:feed between the pigs fed a low-energy diet with CS and the control during the entire 4-wk. In experience 3 (Exp. 3), 100 pigs $(64.1 \pm 1.7 \mathrm{~kg})$ were fed either a control diet (3277 Mcal ME per kg diet) or a low-energy diet (3 168 Mcal ME per kg diet) with $0.05 \% \mathrm{CS}$ for 4-wk. Barrows fed the diet with CS grew faster and had an increased gain:feed $(P<0.05)$ than the control, whereas growth rate and gain:feed of the gilts was not improved by CS. In experience 4 (Exp. 4$), 60$ pigs ( $23.1 \pm 1.7 \mathrm{~kg}$ ) were fed either a control diet or a $0.05 \%$ CS supplemented diet (3 replicates per treatment with 10 pigs per pen). The pigs in each pen were moved to an environmental chamber and aerial ammonia levels were measured for $66 \mathrm{~h}$ at 5 min intervals but the first 18-h was regarded as an acclimation period and the last 48-h was regarded as the data collection period. There was no difference $(P=0.436)$ in the average ammonia concentration between the treatments. However, the increase in ammonia concentration was slower $(P<0.05)$ from pigs fed $0.05 \%$ CS than from pigs fed the control diet. These experiments indicate that the CS supplementation improves nutrient digestibility and could reduce at least $3 \%$ of $\mathrm{ME}$ in swine diets without adverse effects on growth performance.
\end{abstract}

\section{ammonia / carbohydrase / ileal digestibility / pigs / soybean meal}

\footnotetext{
*Corresponding author: sungwoo.kim@ttu.edu
} 
Résumé - Utilisation des carbohydrases dans les régimes à base de farine de maïs-soja chez le porc en croissance-finition. Quatre expériences ont été conduites pour déterminer les effets de l'addition de carbohydrases (CS) dans l'alimentation des porcs sur la digestibilité iléale des nutriments et l'émission d'ammoniac. Les carbohydrases utilisées dans cette étude ont été des enzymes obtenues à partir d'Aspergillus niger et Aspergillus oryzae durant le processus de fermentation. Les principales enzymes actives étaient l' $\alpha$-1,6-galactosidase, la $\beta-1,4$-mannanase, et la $\beta$-1,4-mannosidase qui visent les composés à l'origine de flatulences et présents dans les farines de soja. Dans l'expérience 1 (Exp. 1), 8 porcs castrés cannulés $(93,9 \pm 2.0 \mathrm{~kg})$ ont été alimentés avec des rations supplémentés en CS $(0,00,0,05$ et $0,10 \%)$ pour mesurer la digestibilité iléale des nutriments. Les digestibilités iléales de la lysine, de la thréonine, et du tryptophane ont été améliorées $(P<0,05)$ avec le supplément de CS à $0,05 \%$ et $0,10 \%$, tandis que la digestibilité de la méthionine et des acides aminés à chaînes ramifiées ne s'est pas améliorée. La supplémentation à $0,05 \%$ a augmenté $(P<0,05)$ la digestibilité iléale apparente de l'énergie. Dans l'expérience 2 (Exp. 2), 100 porcs $(24,1 \pm 0.6 \mathrm{~kg})$ ont reçu une ration témoin $(3278 \mathrm{Mcal} \mathrm{ME} / \mathrm{kg}$ ) ou une ration à énergie réduite (3109 Mcal ME/kg) avec $0,05 \%$ de $\mathrm{CS}$ durant 4 semaines. Aucune différence $(P>0,05)$ n'a été observée pour les gains moyens quotidiens, l'ingestion, et l'efficacité alimentaire (gain/ingéré) entre les porcs nourris avec la ration à énergie réduite additionnée de CS et la ration témoin durant toute la durée de l'expérience. Dans l'expérience 3 (Exp. 3), 100 porcs $(64,1 \pm 1.7 \mathrm{~kg}$ ) ont été alimentés avec une ration témoin $(3277 \mathrm{Mcal} \mathrm{ME} / \mathrm{kg}$ ) ou avec une ration à énergie réduite (3168 Mcal ME/kg) supplémentée avec 0,05\% de CS durant 4 semaines. Les porcs castrés alimentés avec la ration additionnée de CS se sont développés plus rapidement et ont eu une efficacité alimentaire (gain/ingéré) accrue $(P<0,05)$ par rapport à ceux recevant la ration témoin, tandis que la vitesse de croissance et l'efficacité alimentaire des jeunes truies n'ont pas été améliorées avec CS. Dans l'expérience 4 (Exp. 4), 60 porcs (23,1 $\pm 1.7 \mathrm{~kg})$ ont été alimentés avec une ration témoin ou une ration additionnée de $0,05 \%$ de CS (3 répétitions par traitement avec 10 porcs par enclos). Les porcs de chaque enclos ont été transférés dans une chambre sous atmosphère contrôlée et les niveaux d'ammoniac dans l'air ont été mesurés pendant $66 \mathrm{~h}$ à intervalles réguliers de 5 minutes. Les premières 18 heures ont été considérées comme une période d'adaptation et les dernières 48 heures comme une période de collecte des données. Il n'y a eu aucune différence $(P=0,436)$ dans la concentration moyenne en ammoniac entre les traitements. Cependant, l'augmentation de la concentration en ammoniac était plus lente $(P<0,05)$ chez les porcs supplémentés avec $0,05 \%$ de CS que chez les porcs alimentés avec le régime témoin. Ces expériences montrent que la supplémentation en CS a amélioré la digestibilité des nutriments et pourrait réduire d'au moins $3 \%$ l'énergie métabolisable dans les rations de porcs sans effets néfastes sur les performances de croissance.

ammoniac / carbohydrase / digestibilité iléale / porcs / farine de soja

\section{INTRODUCTION}

Flatulence-producing compounds (FPC) are heat stable antinutritional compounds in soybean meals that are not destroyed during the processing of soybeans to soybean meal [13]. They are oligo- and polysaccharides including $\alpha$-1,6-galactosides, $\beta$-1,4-mannans, and $\beta$-galactomannans that are resistant to endogenous enzymes produced from the pigs' gastrointestinal tract $[8,10]$. These undigested oligoand poly-saccharides cause reduced digestibility due to increased osmolarity and rate of passage in the gut. The FPC entering the hind-gut are readily fermented by microorganisms causing massive gas production $[7,25,26]$.

Use of exogenous dietary enzymes to hydrolyze FPC in the foregut is the most practical and inexpensive method of minimizing the detrimental effects of FPC in soybean meal. Use of exogenous enzymes targeting FPC in pig diets has been investigated $[3,7,25]$. However, previous studies targeted a specific kind of FPC and the results were not consistent. Recently, Kim et al. [12] demonstrated the benefits of using carbohydrase supplements targeting multiple FPC $(\alpha$-1,6-galactosides, $\beta$-1,4-mannans, and $\beta$-galactomannan) in 
soybean meal based diets of nursery pigs. Both ileal nutrient digestibility and feed efficiency of nursery pigs were improved by this application. The aim of the current study was to determine the effects of this carbohydrase supplement in soybean meal based diets on growth performance, nutrient digestibility, and aerial ammonia emissions of grower-finisher pigs.

\section{MATERIALS AND METHODS}

\subsection{Enzyme}

Characteristics of the carbohydrase (CS) supplement (Endopower ${ }^{\circledR}$, EasyBio System, Seoul, Korea) were previously described [12]. The CS supplement consisted of $40 \%$ dehydrated fermentation product from Aspergillus niger (PRL 2351) and Aspergillus oryzae (ATCC 66222) by weight and $60 \%$ dehydrated barley malt sprouts. The major active enzymes were $\alpha$-1,6-galactosidase, $\beta$-1,4-mannanase, and $\beta$-1,4-mannosidase. Some minor residual enzymes were $\beta$-1,4-glucanase, $\beta$-1,4glucanase, $\beta$-glucosidase, cellobiase, xylosidase, arabinosidase, amiloglucosidase, and $\alpha$-glucosidase.

\subsection{Animal care}

The animal care protocols were approved by the Animal Care and Use Committee of Texas Tech University and by the Laboratory Animal Care Committee of the University of Illinois at UrbanaChampaign.

\subsection{Experience 1}

\subsubsection{Design and animal}

Eight barrows $(93.9 \pm 2.0 \mathrm{~kg})$ were surgically fitted with cannula at the distal ileum using procedures described by
Stein et al. [21, 22] to measure the effect of CS supplementation on ileal digestibility of nutrients in soybean meal by finisher pigs. A Latin square split-plot design was used with two replicates of a $4 \times 4$ Latin square and each Latin square had four barrows. Within each Latin square, four barrows were allotted to treatments randomly within each treatment group and rotated in a random manner such that each pig received each diet.

Each period consisted of $5 \mathrm{~d}$ diet adjustment followed by $2 \mathrm{~d}$ of ileal digesta collection. Within each period of a square, all pigs were fed the same amount of diet each day, equally divided between meals of 0800 and $1800 \mathrm{~h}$. The daily amount fed within a period was $0.09 \mathrm{~kg}$ per $\mathrm{kg}^{0.75}$ based on the average weight of pigs at the beginning of each period.

\subsubsection{Experimental diets}

Cannulated pigs were fed one of four corn-starch based diets. Three diets contained $35 \%$ soybean meal as the sole protein source and one contained 5\% casein as the sole protein source (Tab. I). The soybean meal diets were supplemented with $0,0.05$, or $0.10 \%$ of CS. The lowprotein casein diet was used to measure endogenous protein loss as previously described [9, 22-24] based on an assumption that casein itself is $100 \%$ digestible at a low inclusion level [5].

\subsubsection{Sampling and chemical analyses}

Digesta were collected from 0800 to 2000 during the 2-d collection period. Sterile 225-mL plastic bags (Gerber baby bottle bag, Gerber Products Company, Fremont, MI) were used to collect digesta from cannulated pigs. After removing the cap from the cannula, a plastic bag was attached to the cannula barrel using an autolocking cable tie. Collected 
Table I. Composition of diets for Exp. 1 (as fed basis).

\begin{tabular}{|c|c|c|c|c|}
\hline \multirow[b]{2}{*}{ Ingredient } & \multirow[b]{2}{*}{ Casein } & \multirow[b]{2}{*}{0} & \multicolumn{2}{|c|}{ Carbohydrase (\%) } \\
\hline & & & 0.05 & 0.10 \\
\hline Corn starch & 61.60 & 38.35 & 38.30 & 38.25 \\
\hline Soybean meal, dehulled & & 35.00 & 35.00 & 35.00 \\
\hline Carbohydrases $^{\mathrm{a}}$ & & & 0.05 & 0.10 \\
\hline Casein (food grade) & 5.00 & & & \\
\hline Sucrose & 20.00 & 20.00 & 20.00 & 20.00 \\
\hline Corn oil & 2.00 & 2.00 & 2.00 & 2.00 \\
\hline Salt & 0.40 & 0.35 & 0.35 & 0.35 \\
\hline Cellulose $^{\mathrm{b}}$ & 5.00 & & & \\
\hline Limestone & 0.60 & 0.45 & 0.45 & 0.45 \\
\hline Dicalcium phosphate & 3.00 & 3.00 & 3.00 & 3.00 \\
\hline Potassium carbonate ${ }^{\mathrm{c}}$ & 1.40 & & & \\
\hline Magnesium oxide $^{\mathrm{d}}$ & 0.15 & & & \\
\hline Vitamin premix ${ }^{\mathrm{e}}$ & 0.30 & 0.30 & 0.30 & 0.30 \\
\hline Mineral premix ${ }^{\mathrm{f}}$ & 0.05 & 0.05 & 0.05 & 0.05 \\
\hline $\mathrm{Cr}_{2} \mathrm{O}_{3}$ & 0.50 & 0.50 & 0.50 & 0.50 \\
\hline \multicolumn{5}{|l|}{ Analyzed composition: } \\
\hline $\mathrm{DM}(\%)$ & 92.3 & 92.6 & 92.4 & 92.2 \\
\hline $\mathrm{CP}(\%)$ & 5.8 & 18.7 & 19.0 & 18.4 \\
\hline Ash (\%) & 6.4 & 6.2 & 6.3 & 6.4 \\
\hline Lysine (\%) & 0.39 & 1.05 & 1.00 & 1.08 \\
\hline Threonine (\%) & 0.21 & 0.66 & 0.64 & 0.68 \\
\hline Tryptophan (\%) & 0.07 & 0.21 & 0.26 & 0.27 \\
\hline Methionine (\%) & 0.13 & 0.24 & 0.23 & 0.24 \\
\hline Gross energy ( $\mathrm{kcal}$ per $\mathrm{kg}$ ) & 3969 & 4187 & 4182 & 4174 \\
\hline
\end{tabular}

${ }^{a}$ Carbohydrases (Endopower ${ }^{\circledR}$, EasyBio System Inc., Seoul, Korea) were composed of dehydrated fermentation products from Aspergillus niger (PRL 2351) and Aspergillus oryzae (ATCC 66222) (40\% by weight) and dehydrated barley malt sprouts ( $60 \%$ by weight). Main active forms in fermentation products are $\alpha$-1,6-galactosidase, $\beta$-1,4-mannanase, and $\beta$-1,4-mannosidase. One kilogram of complete diets contained 7 units of $\alpha$-1,6-galactosidase and 22 units of $\beta$-1,4-mannanase for $0.1 \%$ carbohydrase supplementation and 3.5 units of $\alpha$-1,6-galactosidase and 11 units of $\beta$-1,4-mannanase for $0.05 \%$ carbohydrase supplementation.

${ }^{\mathrm{b}}$ Solka floc ${ }^{\circledR}$ (Fiber Sales \& Development Corp., Urbana, OH).

${ }^{\mathrm{c}}$ Potassium carbonate contains 55\% potassium (K) as-fed basis (Fisher Scientific, Pittsburgh, PA).

${ }^{\mathrm{d}}$ Magnesium oxide contains 58\% magnesium (Mg) as-fed basis (Fisher Scientific, Pittsburgh, PA).

${ }^{\mathrm{e}}$ The vitamin premix provided the following per kilogram of complete diet: $2000 \mathrm{IU}$ vitamin A as vitamin A acetate, $300 \mathrm{IU}$ vitamin $\mathrm{D}_{3}, 20 \mathrm{IU}$ vitamin $\mathrm{E}, 1.0 \mathrm{mg}$ vitamin $\mathrm{K}$ as menadione sodium bisulfite, $4 \mathrm{mg}$ thiamin, $15 \mathrm{mg}$ niacin, $4 \mathrm{mg}$ riboflavin, $12 \mathrm{mg}$ D-pantothenic acid as calcium pantothenate, $15 \mu \mathrm{g}$ vitamin $\mathrm{B}_{12}, 2 \mathrm{mg}$ pyridoxine, $1 \mathrm{mg}$ d-biotin, $5 \mathrm{mg}$ folic acid, and $0.60 \mathrm{~g}$ choline as choline chloride.

${ }^{\mathrm{f}}$ The mineral premix provided the following per kilogram of complete diet: $90 \mathrm{mg}$ iron as iron sulfate, $5 \mathrm{mg}$ manganese as manganese oxide, $8 \mathrm{mg}$ copper as copper oxide, $20 \mathrm{mg}$ iodide as potassium iodate, $0.21 \mathrm{mg}$ selenium as sodium selenite, and $90 \mathrm{mg}$ zinc as zinc oxide. 
samples were placed in plastic containers and frozen at $-20{ }^{\circ} \mathrm{C}$ immediately after collection. Frozen ileal samples were freeze-dried and ground using an analytical mill (A10 S2, IKA-Laboratechnik, Germany) prior to chemical analyses. Samples were analyzed for dry matter by desiccation at $105{ }^{\circ} \mathrm{C}$ for $4 \mathrm{~h}$, ash by combustion at $500{ }^{\circ} \mathrm{C}$ for $8 \mathrm{~h}$, and crude protein by measuring nitrogen content (Kjeldahl method; [2]). Separation and analysis of the amino acids was performed on an amino acid analyzer (Beckman 6300, Beckman Coulter, Inc., Fullerton, CA) equipped with a high performance cation exchange resin column with amino acid detection accomplished with post-column ninhydrin derivatization. Norleucine was utilized as the internal standard. Tryptophan was quantified after alkaline hydrolysis of the samples [16]. Gross energy was measured by combustion using a bomb calorimeter (Parr 1261, Parr Instrument Co., Molin, IL). Chromium content was measured from ashed samples [28].

\subsubsection{Calculations and statistical analysis}

Apparent and standardized digestibilities were calculated as previously described by van Kempen et al. [24]. Endogenous amino acid losses determined using the low-protein casein diet were used to calculate standardized digestibility.

Data were analyzed using a Latin Square split plot design (two replicates of $4 \times 4$ Latin Square design) as previously described by Kim and Easter [11]. Analyses were performed using the PROC ANOVA procedure in SAS/STAT ${ }^{\circledR}$ software (SAS Inst., Inc., Cary, NC).

\subsection{Experiences 2 and 3}

\subsubsection{Design and animals}

A total of 200 pigs was used to determine the effect of CS supplementation to low ME diets on growth performance of grower and finisher pigs. Experiment 2 used one hundred grower pigs $(24.1 \pm 0.6 \mathrm{~kg})$ and Exp. 3 used $100 \mathrm{fin}$ isher pigs $(64.1 \pm 1.7 \mathrm{~kg})$. In both experiments, pigs were allotted to one of two treatments to provide 10 replicates of five pigs each per treatment. For each treatment, there were 5 replicates of gilts and 5 replicates of barrows. Grower pigs were housed in $1.4 \times 2.4 \mathrm{~m}$ pens and finisher pigs were housed in $1.8 \times 2.6$ in a totally slatted floor confinement facility, and had ad libitum access to diet and water. Feed intake and body weight were measured each week of the 4 wk experiments.

\subsubsection{Experimental diets}

Diets were based on corn and soybean meal, and met or exceeded the nutrient requirements specified by the NRC [17] (Tab. II). Calculated ME and total lysine contents of the control diets were $3278 \mathrm{kcal}$ per $\mathrm{kg}$ and $1.04 \%$ for Exp. 2 and $3277 \mathrm{kcal}$ per $\mathrm{kg}$ and $0.86 \%$ for Exp. 3 . The test diets were similar to the control diets except $0.05 \%$ CS was added and purified cellulose replaced soybean oil to lower the ME content. The CS diets had 95\% and $97 \%$ of the ME in the control diets for Exp. 2 and 3, respectively. The results of Exp. 1 indicated that addition of $0.05 \%$ CS improved digestibility of gross energy and the levels of ME in the CS diets were determined based on the results from Exp. 1.

\subsubsection{Statistical analyses}

Data were analyzed as a randomized complete block design with sex as a block criterion. Analyses were performed using PROC GLM procedure of SAS (SAS Inst., Inc., Cary, NC). Effects of treatment, sex, and interaction of treatment and sex were included in the model. Leastsquares means, probabilities of differences, 
Table II. Composition of diets for Exp. 2 and Exp. 3 (as fed basis).

\begin{tabular}{|c|c|c|c|c|}
\hline \multirow[b]{2}{*}{ Ingredient } & \multicolumn{2}{|c|}{ Exp. 2} & \multicolumn{2}{|c|}{ Exp. 3} \\
\hline & Control & Carbohydrases & Control & Carbohydrases \\
\hline Corn & 55.60 & 55.60 & 57.40 & 57.40 \\
\hline Soybean meal (48\%) & 27.00 & 27.00 & 20.00 & 20.00 \\
\hline Wheat bran & 13.00 & 13.00 & 17.00 & 17.00 \\
\hline Soybean oil & 2.00 & 0.00 & 3.00 & 1.70 \\
\hline Cellulose ${ }^{\mathrm{a}}$ & 0.00 & 1.95 & 0.85 & 2.10 \\
\hline Limestone & 0.90 & 0.90 & 0.60 & 0.60 \\
\hline Dicalcium phosphate & 1.00 & 1.00 & 0.70 & 0.70 \\
\hline Mineral-salt premix ${ }^{\mathrm{b}}$ & 0.35 & 0.35 & 0.30 & 0.30 \\
\hline Vitamin premix ${ }^{\mathrm{c}}$ & 0.10 & 0.10 & 0.10 & 0.10 \\
\hline Additive $^{\mathrm{d}}$ & 0.05 & 0.05 & 0.05 & 0.05 \\
\hline Carbohydrases $^{\mathrm{e}}$ & 0.00 & 0.05 & 0.00 & 0.05 \\
\hline \multicolumn{5}{|l|}{ Calculated composition $^{\mathrm{f}}$} \\
\hline ME (kcal per kg) & 3278 & 3109 & 3277 & 3168 \\
\hline Crude protein (\%) & 19.48 & 19.48 & 16.93 & 16.93 \\
\hline Lysine (\%) & 1.04 & 1.04 & 0.86 & 0.86 \\
\hline Threonine (\%) & 0.73 & 0.73 & 0.62 & 0.62 \\
\hline Tryptophan (\%) & 0.24 & 0.24 & 0.20 & 0.20 \\
\hline Methionine+Cystine (\%) & 0.66 & 0.66 & 0.59 & 0.59 \\
\hline Available phosphorus (\%) & 0.29 & 0.29 & 0.24 & 0.24 \\
\hline Calcium (\%) & 0.73 & 0.73 & 0.52 & 0.52 \\
\hline \multicolumn{5}{|l|}{ Analyzed composition ${ }^{\mathrm{f}}$} \\
\hline GE (kcal per kg) & 4183 & 3962 & 4142 & 4014 \\
\hline
\end{tabular}

${ }^{\text {a }}$ Solka Floc ${ }^{\circledR}$ (Fiber Sales \& Development Corp., Urbana, OH).

${ }^{b}$ The mineral-salt premix provided the following per kilogram of complete diet: $20 \mathrm{mg}$ manganese as manganous oxide, $90 \mathrm{mg}$ iron as iron sulfate, $100 \mathrm{mg}$ zinc as zinc oxide, $8 \mathrm{mg}$ copper as copper oxide, $0.35 \mathrm{mg}$ iodide as ethylenediamine dihydroiodide and $0.3 \mathrm{mg}$ selenium as sodium selenite.

${ }^{\mathrm{c}}$ The vitamin premix provided the following per kilogram of complete diet: $3306.9 \mathrm{IU}$ vitamin A as vitamin $A$ acetate, 330.7 IU vitamin $\mathrm{D}_{3}, 44.1 \mathrm{IU}$ vitamin $\mathrm{E}, 2.2 \mathrm{IU}$ vitamin $\mathrm{K}$ as menadione sodium bisulfite, $3.7 \mu \mathrm{g}$ vitamin $\mathrm{B}_{12}, 0.9 \mathrm{mg}$ riboflavin, $2.5 \mathrm{mg}$ D-pantothenic acid as calcium pantothenate, $3.4 \mathrm{mg}$ niacin and $25.0 \mathrm{mg}$ choline as choline chloride.

${ }^{\mathrm{d}}$ Tylan ${ }^{\circledR}$ (Elanco, IN).

${ }^{\mathrm{e}}$ Carbohydrases (Endopower ${ }^{\circledR}$, EasyBio System Inc., Seoul, Korea) were composed of dehydrated fermentation products from Aspergillus niger (PRL 2351) and Aspergillus oryzae (ATCC 66222) (40\% by weight) and dehydrated barley malt sprouts ( $60 \%$ by weight). Main active forms in fermentation products are $\alpha$-1,6-galactosidase, $\beta$-1,4-mannanase, and $\beta$-1,4-mannosidase. One kilogram of complete diets contained 3.5 units of $\alpha$-1,6-galactosidase and 11 units of $\beta$-1,4-mannanase for $0.05 \%$ carbohydrase supplementation.

${ }_{\mathrm{f}}^{\mathrm{P}}$ As-fed basis. 
and standard errors of the mean were obtained to evaluate differences among treatment means.

\subsection{Experience 4}

\subsubsection{Design and animals}

Sixty pigs $(23.1 \pm 1.7 \mathrm{~kg})$ were used in Exp. 4 to measure the effects of CS supplementation to a corn-soybean meal based diet on aerial ammonia emission by grower pigs. Pigs were randomly allotted to either the control treatment or the CS treatment. Each treatment had three replicates with 10 pigs per pen-replicate. Pigs were housed in $1.4 \times 2.4 \mathrm{~m}$ pens in a totally slatted floor confinement facility, and had ad libitum access to diet and water.

The control diet was based on corn and soybean meal (Tab. III) and the CS diet contained $0.05 \% \mathrm{CS}$ by replacing the same amount of corn (Tab. III).

An environmental chamber was used to measure aerial ammonia concentration from the pigs under controlled conditions. Ten pigs from each pen were moved to a pen $(1.2 \times 2.4 \mathrm{~m})$ in a ventilated environmental chamber $(3.0 \times 3.0 \times 2.4 \mathrm{~m})$ for $66 \mathrm{~h}$ during which aerial ammonia was measured. The temperature inside of the chamber was maintained at $24{ }^{\circ} \mathrm{C}$ and the fan was working continuously during the experimental period. A gas monitor (Pac III, Draeger Safety, Inc., Pittsburgh, PA) with sensors for ammonia and hydrogen sulfide was used to measure the changes in air concentration of these compounds during the $66 \mathrm{~h}$ collection period at 5 min intervals. Feed intake of pigs during the $66 \mathrm{~h}$ collection period was measured. Body weights were measured before and after moving pigs to the chamber. The first 18-h was regarded as an acclimation period and the last 48-h was regarded as a data collection period.
Table III. Composition of diets for Exp. 4 (as fed basis).

\begin{tabular}{lcc}
\hline Ingredient & Control & Carbohydrases \\
\hline Corn & 69.00 & 68.95 \\
Soybean meal, & & \\
dehulled & 26.00 & 26.00 \\
Salt & 0.30 & 0.30 \\
Vitamin-mineral & & \\
premix $^{\mathrm{a}}$ & 2.00 & 2.00 \\
Soybean oil & 1.00 & 1.00 \\
Dicalcium phosphate & 1.00 & 1.00 \\
Limestone & 0.70 & 0.70 \\
Carbohydrases & \\
Total & 0.00 & 0.05 \\
\hline Calculated analysis & & \\
Dry matter $(\%)$ & 100.00 & 100.00 \\
ME (kcal per kg) & 3355.1 & 3355.1 \\
CP $(\%)$ & 18.2 & 18.2 \\
Lysine (\%) & 0.97 & 0.97 \\
Met + Cys (\%) & 0.62 & 0.62 \\
Tryptophan $(\%)$ & 0.21 & 0.21 \\
Threonine $(\%)$ & 0.68 & 0.68 \\
Calcium $(\%)$ & 0.62 & 0.62 \\
Available & & \\
phosphorus $(\%)$ & 0.27 & 0.27 \\
\hline a & & \\
\hline
\end{tabular}

${ }^{a}$ Vitamin-mineral premix provided the following per kilogram of complete diet: $31.1 \mathrm{mg}$ manganese as manganous oxide, $50 \mathrm{mg}$ iron as iron sulfate, $69.2 \mathrm{mg}$ zinc as zinc oxide, $6.3 \mathrm{mg}$ copper as copper oxide, $0.48 \mathrm{mg}$ iodide as ethylenediamine dihydroiodide, $0.15 \mathrm{mg}$ selenium as sodium selenite, 5037 IU vitamin A as vitamin A acetate, 550 IU vitamin $\mathrm{D}_{3}, 41.3 \mathrm{IU}$ vitamin $\mathrm{E}, 1.8 \mathrm{IU}$ vitamin $\mathrm{K}$ as menadione sodium bisulfite, $36.6 \mu \mathrm{g}$ vitamin $\mathrm{B}_{12}$, $9.2 \mathrm{mg}$ riboflavin, $29.3 \mathrm{mg}$ D-pantothenic acid as calcium pantothenate, $36.6 \mathrm{mg}$ niacin and $1105 \mathrm{mg}$ choline as choline chloride.

b Carbohydrases (Endopower ${ }^{\circledR}$, EasyBio System Inc., Seoul, Korea) were composed of dehydrated fermentation products from Aspergillus niger (PRL 2351) and Aspergillus oryzae (ATCC 66222) (40\% by weight) and dehydrated barley malt sprouts ( $60 \%$ by weight). Main active forms in fermentation products are $\alpha$-1,6-galactosidase, $\beta$-1,4-mannanase, and $\beta$-1,4-mannosidase. One kilogram of complete diets contained 3.5 units of $\alpha$-1,6-galactosidase and 11 units of $\beta-1,4$ mannanase for $0.05 \%$ carbohydrase supplementation.

c As-fed basis. 


\subsubsection{Statistical analysis}

Data were analyzed as a randomized complete block design. Analyses were performed using PROC GLM procedure of SAS (SAS Inst., Inc., Cary, NC). Leastsquares means of the aerial ammonia levels during the last $10,20,30$, and $48 \mathrm{~h}$ as well as the body weight of pigs and feed consumption from each treatment were obtained. The probabilities of differences, and standard errors of the mean were obtained to evaluate differences among treatment means. Feed intake and initial body weight were used as covariates in analyzing the data. Equations describing the increases in aerial ammonia levels in the chamber during the $48 \mathrm{~h}$ were obtained and the slopes of equations for each treatment were compared as previously described by Kim and Easter [11].

\section{RESULTS}

\subsection{Experience 1}

Initial weight of cannulated pigs was $93.9 \pm 2.0 \mathrm{~kg}$ and the final weight was $116.8 \pm 1.8 \mathrm{~kg}$. The average daily gain was $817.0 \pm 43.6 \mathrm{~g}$. Daily feed allowance was $2.70,2.85,2.95$, and $3.10 \mathrm{~kg}$ for periods $1,2,3$, and 4 , respectively.

\subsubsection{Energy, dry matter, and ash}

Apparent ileal digestibility of GE and DM were greater $(P<0.05)$ when $0.05 \%$ CS was supplemented to the soybean meal based diet (Tab. IV). The improvement in energy digestibility averaged 3\%. Supplementing CS at the $0.10 \%$ level, on the other hand, did not improve either apparent ileal digestibility of gross energy or DM. Carbohydrase supplementation did not affect apparent ileal digestibility of ash.
Table IV. Effect of carbohydrase supplementation on apparent ileal digestibility of nutrients in soybean meal (Exp. 1) .

\begin{tabular}{|c|c|c|c|c|}
\hline & \multicolumn{4}{|c|}{ Carbohydrases } \\
\hline & Control & $0.05 \%$ & $0.10 \%$ & SEM $^{\mathrm{b}}$ \\
\hline$\overline{\mathrm{GE}}$ & $82.0^{c}$ & $84.3^{\mathrm{d}}$ & $82.4^{\mathrm{c}}$ & 0.33 \\
\hline DM & $81.1^{\mathrm{c}}$ & $83.3^{\mathrm{d}}$ & $82.2^{\mathrm{cd}}$ & 0.39 \\
\hline Ash & 37.0 & 35.3 & 41.6 & 1.43 \\
\hline $\mathrm{CP}$ & $78.9^{c}$ & $81.7^{\mathrm{d}}$ & $79.3^{\mathrm{cd}}$ & 0.58 \\
\hline \multicolumn{5}{|l|}{$\begin{array}{l}\text { Essential amino } \\
\text { acids }\end{array}$} \\
\hline Arginine & $90.8^{\mathrm{c}}$ & $94.1^{\mathrm{d}}$ & $93.6^{\mathrm{cd}}$ & 0.59 \\
\hline Histidine & $85.6^{c}$ & $89.1^{\mathrm{d}}$ & $87.5^{\mathrm{cd}}$ & 0.54 \\
\hline Isoleucine & 80.9 & 80.9 & 82.2 & 0.58 \\
\hline Leucine & 83.0 & 84.1 & 84.7 & 0.55 \\
\hline Lysine & $85.2^{\mathrm{c}}$ & $86.9^{d}$ & $87.3^{\mathrm{d}}$ & 0.36 \\
\hline Methionine & 85.8 & 87.3 & 87.2 & 0.33 \\
\hline Phenylalanine & 84.1 & 86.0 & 86.0 & 0.42 \\
\hline Threonine & $74.9^{c}$ & $77.7^{\mathrm{d}}$ & $77.8^{\mathrm{d}}$ & 0.55 \\
\hline Tryptophan & $80.8^{c}$ & $87.0^{\mathrm{d}}$ & $86.6^{\mathrm{d}}$ & 0.84 \\
\hline Valine & 79.1 & 79.5 & 80.4 & 0.59 \\
\hline \multicolumn{5}{|l|}{$\begin{array}{l}\text { Non-essential } \\
\text { amino acids }\end{array}$} \\
\hline Alanine & 74.0 & 72.7 & 75.1 & 0.65 \\
\hline Aspartate & $79.9^{c}$ & $82.6^{\mathrm{d}}$ & $81.2^{\mathrm{cd}}$ & 0.48 \\
\hline Cysteine & $77.2^{\mathrm{c}}$ & $81.0^{\mathrm{d}}$ & $78.3^{\mathrm{c}}$ & 0.54 \\
\hline Glutamate & $78.4^{\mathrm{c}}$ & $84.8^{\mathrm{d}}$ & $80.6^{\mathrm{c}}$ & 0.77 \\
\hline Glycine & $65.5^{c}$ & $70.1^{\mathrm{d}}$ & $66.7^{\mathrm{c}}$ & 0.64 \\
\hline Proline & 77.5 & 78.6 & 75.9 & 1.64 \\
\hline Serine & $81.2^{\mathrm{c}}$ & $83.5^{\mathrm{cd}}$ & $83.7^{\mathrm{d}}$ & 0.51 \\
\hline Taurine & $84.4^{c}$ & $88.1^{\mathrm{d}}$ & $82.8^{c}$ & 0.80 \\
\hline Tyrosine & $84.4^{c}$ & $87.6^{\mathrm{d}}$ & $87.5^{\mathrm{d}}$ & 0.52 \\
\hline All amino acids & $80.7^{\mathrm{c}}$ & $83.3^{\mathrm{d}}$ & $82.4^{\mathrm{cd}}$ & 0.48 \\
\hline
\end{tabular}

a Values are means for eight pigs used in a replicated $4 \times 4$ Latin Square designed experiment.

${ }^{b}$ Pooled standard error of the means.

$\mathrm{c}, \mathrm{d}$ Within a row, means without a common superscript letter differ $(P<0.05)$.

\subsubsection{Crude protein and amino acids}

Apparent ileal digestibility of $\mathrm{CP}$ was improved about 3\% $(P<0.05)$ when $0.05 \%$ CS was supplemented to the diet. Supplementing $0.10 \%$ CS, did not affect apparent CP digestibility. Standardized 
Table V. Effect of carbohydrase supplementation on the standardized ileal digestibility of crude protein and amino acids in soybean meal (Exp. 1) .

\begin{tabular}{lcccc}
\hline & & \multicolumn{2}{c}{ Carbohydrases } & \\
\cline { 3 - 4 } & Control & $0.05 \%$ & $0.10 \%$ & SEM $^{\mathrm{b}}$ \\
\hline CP & 85.4 & 87.9 & 85.9 & 0.79 \\
Essential amino & & & & \\
acids & & & & \\
Arginine & $93.5^{\mathrm{c}}$ & $97.0^{\mathrm{d}}$ & $96.3^{\mathrm{cd}}$ & 0.63 \\
Histidine & $88.6^{\mathrm{c}}$ & $91.1^{\mathrm{d}}$ & $90.3^{\mathrm{cd}}$ & 0.61 \\
Isoleucine & 86.5 & 87.0 & 87.8 & 0.67 \\
Leucine & 86.3 & 87.7 & 88.0 & 0.63 \\
Lysine & $88.2^{\mathrm{c}}$ & $90.1^{\mathrm{d}}$ & $90.3^{\mathrm{d}}$ & 0.41 \\
Methionine & 89.1 & 90.8 & 90.6 & 0.38 \\
Phenylalanine & $86.6^{\mathrm{c}}$ & $88.6^{\mathrm{d}}$ & $88.4^{\mathrm{cd}}$ & 0.48 \\
Threonine & $82.4^{\mathrm{c}}$ & $85.5^{\mathrm{d}}$ & $85.1^{\mathrm{d}}$ & 0.64 \\
Tryptophan & $86.4^{\mathrm{c}}$ & $91.5^{\mathrm{d}}$ & $90.9^{\mathrm{d}}$ & 0.85 \\
Valine & 84.7 & 85.5 & 85.9 & 0.70 \\
Non-essential & & & & \\
amino acids & & & & \\
Alanine & $80.2^{\mathrm{n}}$ & 79.2 & 81.1 & 0.72 \\
Aspartate & $83.3^{\mathrm{c}}$ & $86.1^{\mathrm{d}}$ & $84.5^{\mathrm{cd}}$ & 0.54 \\
Cysteine & $82.1^{\mathrm{c}}$ & $86.1^{\mathrm{d}}$ & $83.5^{\mathrm{c}}$ & 0.63 \\
Glutamate & $82.3^{\mathrm{c}}$ & $88.8^{\mathrm{d}}$ & $84.3^{\mathrm{c}}$ & 0.84 \\
Glycine & $76.8^{\mathrm{c}}$ & $81.8^{\mathrm{d}}$ & $77.6^{\mathrm{c}}$ & 0.92 \\
Proline & 102.1 & 104.4 & 100.3 & 1.73 \\
Serine & $89.6^{\mathrm{c}}$ & $92.2^{\mathrm{d}}$ & $92.2^{\mathrm{d}}$ & 0.62 \\
Taurine & $97.1^{\mathrm{c}}$ & $101.8^{\mathrm{d}}$ & $96.5^{\mathrm{c}}$ & 1.14 \\
Tyrosine & $88.1^{\mathrm{c}}$ & $91.6^{\mathrm{d}}$ & $91.2^{\mathrm{d}}$ & 0.55 \\
Mean of all & & & & \\
amino acids & $86.3^{\mathrm{c}}$ & $89.2^{\mathrm{d}}$ & $87.9^{\mathrm{cd}}$ & 0.58 \\
\hline & & & &
\end{tabular}

${ }^{a}$ Values are means for eight pigs used in a replicated $4 \times 4$ Latin Square designed experiment.

${ }^{\mathrm{b}}$ Pooled standard error of the means.

${ }^{\mathrm{c}, \mathrm{d}}$ Within a row, means without a common superscript letter differ $(P<0.05)$.

digestibilities (Tab. V) of CP were similar among treatments.

Supplementing CS either at the $0.05 \%$ or $0.10 \%$ level improved $(P<0.05)$ both apparent and standardized ileal digestibilities of major limiting essential amino acids, including lysine, threonine, and tryptophan. There was no improvement in ileal digestibility of methionine and branched-chain amino acids with the CS supplement. Apparent and standardized ileal digestibilities of histidine and arginine were the greatest $(P<0.05)$ when CS was supplemented at $0.05 \%$. In general, ileal digestibilities of non-essential amino acids were improved $(P<0.05)$ with $0.05 \%$ CS supplementation with the exceptions of alanine and proline.

The mean of amino acid digestibilities was improved $(P<0.05)$ with $0.05 \%$ CS supplementation. The 3\% improvement occurred for both apparent and standardized ileal digestibilities.

\subsubsection{Endogenous loss of amino acids}

The total amount of amino acids lost in endogenous excretions was $9.15 \mathrm{~g}$ per $\mathrm{kg}$ of dry matter intake (Tab. VI). Endogenous losses of lysine, threonine, and tryptophan were $0.31,0.49$, and $0.11 \mathrm{~g}$ per kg dry matter intake.

\subsection{Experience 2}

No differences $(P>0.05)$ were observed for ADG as affected by the dietary treatments or by the sexes during each week and during the entire experimental period (Tab. VII). No interactions $(P>0.05)$ between the treatment and the sex were observed for ADG during each week and during the entire experimental period. No differences $(P>0.05)$ were observed for ADFI as affected by the dietary treatments or by the sexes during the first, second, and third wk. During the fourth wk, pigs fed the low energy diet with CS supplement had a higher feed intake $(P<0.05)$ than pigs fed the control diet. However, there was no difference in average daily feed intake during the entire 
Table VI. Endogenous amino acid loss ( $g$ per kg dry matter intake) observed with a low casein $\operatorname{diet}^{\mathrm{a}}$.

\begin{tabular}{|c|c|c|}
\hline & Low-protein casein diet & $\mathrm{SEM}^{\mathrm{b}}$ \\
\hline \multicolumn{3}{|l|}{ Essential amino } \\
\hline \multicolumn{3}{|l|}{ acids } \\
\hline Arginine & 0.326 & 0.070 \\
\hline Histidine & 0.131 & 0.032 \\
\hline Isoleucine & 0.406 & 0.054 \\
\hline Leucine & 0.443 & 0.083 \\
\hline Lysine & 0.310 & 0.055 \\
\hline Methionine & 0.077 & 0.011 \\
\hline Phenylalanine & 0.208 & 0.042 \\
\hline Threonine & 0.486 & 0.058 \\
\hline Tryptophan & 0.113 & 0.021 \\
\hline Valine & 0.435 & 0.063 \\
\hline \multicolumn{3}{|l|}{ Non-essential } \\
\hline \multicolumn{3}{|l|}{ amino acids } \\
\hline Alanine & 0.460 & 0.072 \\
\hline Aspartate & 0.645 & 0.129 \\
\hline Cysteine & 0.145 & 0.030 \\
\hline Glutamate & 1.185 & 0.175 \\
\hline Glycine & 0.792 & 0.226 \\
\hline Proline & 1.971 & 0.499 \\
\hline Serine & 0.620 & 0.071 \\
\hline Taurine & 0.159 & 0.034 \\
\hline Tyrosine & 0.197 & 0.020 \\
\hline \multicolumn{3}{|l|}{ All amino } \\
\hline acids & 9.145 & 1.641 \\
\hline
\end{tabular}

a Values are means for eight pigs used in a replicated $4 \times 4$ Latin Square designed experiment.

${ }^{\mathrm{b}}$ Standard error of the means.

experimental period as affected by the dietary treatment or by the sex. No interactions $(P>0.05)$ between the treatment and the sex were observed for ADFI during each week and during the entire experimental period. Gain:feed ratio did not differ between the treatments either by week or during the entire experimental period as affected by the dietary treatment or by sex. No interactions $(P>0.05)$ between the treatment and sex were observed for gain:feed during each week and during the entire experimental period.

\subsection{Experience 3}

Pigs fed the low energy diet ( $97 \%$ of the ME content of the control diet) with $0.05 \%$ CS had a higher $(P<0.05)$ ADG than pigs fed the control diet during the entire experimental period (Tab. VIII). However, there was no effect of sex and the interaction of the treatment and sex on ADG of pigs during the entire experimental period. Average daily feed intake was not affected by the treatment, sex, and the interaction of the treatment and sex during the entire experimental period but only except during the third wk. Gain:feed ratio of pigs fed the low energy diet with the CS supplement was not different $(P>0.05)$ to the control pigs during the entire experimental period. However, gain:feed ratio of the gilts tended $(P=0.052)$ to be higher than those of the barrows. There was no interaction between the dietary treatment and the sex for gain:feed ratio during the entire experimental period.

\subsection{Experience 4}

The initial body weight, ADG, and ADFI of pigs were the same $(P>0.05)$ between the control and the CS groups (Tab. IX). The initial aerial ammonia concentrations after the 18-h adjustment period were the same $(P=0.958)$ between the control diet $(19.52 \pm 1.05 \mathrm{ppm})$ and the CS $(19.54 \pm 1.05 \mathrm{ppm})$. Aerial ammonia concentrations from pigs fed the CS supplemented diet were lower $(P<0.05)$ at $29,30,31,32,33,35,39,40$, and $41 \mathrm{~h}$ of the collection period than those from the control group (Fig. 1). The average 
Table VII. Effect of carbohydrase supplementation on growth performance of grower pigs (Exp. 2) ${ }^{\mathrm{a}}$.

\begin{tabular}{|c|c|c|c|c|c|c|c|c|}
\hline \multirow{2}{*}{$\begin{array}{l}\text { Treatment }(T) \\
\operatorname{Sex}(S)\end{array}$} & \multicolumn{2}{|c|}{ Control } & \multicolumn{2}{|c|}{ Carbohydrases $^{\mathrm{b}}$} & \multirow[b]{2}{*}{$\mathrm{SEM}^{\mathrm{c}}$} & \multicolumn{3}{|c|}{$P$ values ${ }^{\mathrm{d}}$} \\
\hline & Barrow & Gilt & Barrow & Gilt & & $\mathrm{T}$ & $\mathrm{S}$ & $\mathrm{T} \times \mathrm{S}$ \\
\hline Initial wt (kg) & 22.9 & 24.5 & 24.0 & 25.0 & 0.6 & 0.432 & 0.207 & 0.792 \\
\hline Final wt (kg) & 43.3 & 44.7 & 44.5 & 44.5 & 0.5 & 0.620 & 0.539 & 0.531 \\
\hline \multicolumn{9}{|c|}{ Average daily gain (g) } \\
\hline Wk 1 & 660.9 & 525.0 & 589.6 & 469.4 & 58.6 & 0.578 & 0.271 & 0.948 \\
\hline Wk 2 & 930.8 & 813.0 & 846.0 & 811.4 & 55.1 & 0.356 & 0.116 & 0.374 \\
\hline Wk 3 & 791.9 & 1021.5 & 837.3 & 957.1 & 76.7 & 0.948 & 0.242 & 0.705 \\
\hline Wk 4 & 518.5 & 521.5 & 659.1 & 544.5 & 60.1 & 0.543 & 0.679 & 0.661 \\
\hline Wk 1 to 4 & 725.3 & 720.2 & 733.0 & 695.6 & 16.9 & 0.815 & 0.561 & 0.655 \\
\hline \multicolumn{9}{|c|}{ Average daily feed intake (kg) } \\
\hline Wk 1 & 1.29 & 1.22 & 1.28 & 1.26 & 0.05 & 0.895 & 0.598 & 0.745 \\
\hline Wk 2 & 1.68 & 1.62 & 1.69 & 1.54 & 0.04 & 0.672 & 0.148 & 0.531 \\
\hline Wk 3 & 1.80 & 1.74 & 1.76 & 1.71 & 0.03 & 0.466 & 0.275 & 0.870 \\
\hline Wk 4 & 1.69 & 1.76 & 1.94 & 1.84 & 0.04 & 0.032 & 0.871 & 0.252 \\
\hline Wk 1 to 4 & 1.61 & 1.58 & 1.67 & 1.59 & 0.03 & 0.607 & 0.347 & 0.677 \\
\hline \multicolumn{9}{|l|}{ Gain:feed ratio } \\
\hline Wk 1 & 0.50 & 0.39 & 0.45 & 0.35 & 0.04 & 0.521 & 0.151 & 0.916 \\
\hline Wk 2 & 0.55 & 0.50 & 0.50 & 0.51 & 0.03 & 0.367 & 0.463 & 0.189 \\
\hline Wk 3 & 0.45 & 0.60 & 0.49 & 0.57 & 0.05 & 0.917 & 0.191 & 0.716 \\
\hline Wk 4 & 0.32 & 0.30 & 0.34 & 0.30 & 0.03 & 0.877 & 0.683 & 0.876 \\
\hline Wk 1 to 4 & 0.45 & 0.45 & 0.44 & 0.44 & 0.01 & 0.567 & 0.990 & 0.920 \\
\hline
\end{tabular}

${ }^{a}$ Values are means of five pens containing five pigs each.

${ }^{\mathrm{b}}$ Diet contained $0.05 \%$ carbohydrase supplementation.

${ }^{\mathrm{c}}$ Pooled standard error of the means.

${ }^{\mathrm{d}} P$ values for difference between the treatments $(\mathrm{T})$, between the sexes $(\mathrm{S})$, and interaction $(\mathrm{T} \times \mathrm{S})$ of the treatment and the sex.

aerial ammonia concentrations during the entire $48 \mathrm{~h}$ collection period did not differ $(P>0.05)$ between the groups but the CS group had the lower $(P<0.05)$ average values than the control group during the last $20 \mathrm{~h}$ collection period ( 29 to $48 \mathrm{~h}$ of the collection period) (Tab. IX).

Changes in aerial ammonia concentrations from both groups were described by linear equations to test the differences between the slopes of the models as described by Kim and Easter [11]. Both models shared the common intercepts for this analysis. The aerial ammonia concentrations (ppm) produced from the control group and the CS supplemented group were modeled as aerial ammonia $(\mathrm{ppm})=19.530+$ $0.223 \times$ time $(\mathrm{h})\left(\mathrm{R}^{2}=0.93, P<0.001\right)$ and aerial ammonia $(\mathrm{ppm})=19.530+$ $0.176 \times$ time $(\mathrm{h})\left(\mathrm{R}^{2}=0.93, P<0.001\right)$, respectively (Fig. 1). The slope of the aerial ammonia changes from the control groups was different $(P<0.001)$ from that of the CS supplemented group indicating that the increase of the aerial ammonia content was slower $(P<0.001)$ from the pigs fed the CS supplemented diet than those fed the control diet. 
Table VIII. Effect of carbohydrase supplementation on growth performance of finisher pigs (Exp. 3) .

\begin{tabular}{|c|c|c|c|c|c|c|c|c|}
\hline \multirow{2}{*}{$\begin{array}{l}\text { Treatment }(T) \\
\text { Sex }(\mathrm{S})\end{array}$} & \multicolumn{2}{|c|}{ Control } & \multicolumn{2}{|c|}{ Carbohydrases $^{\mathrm{b}}$} & \multirow[b]{2}{*}{$\mathrm{SEM}^{\mathrm{c}}$} & \multicolumn{3}{|c|}{$P$ values $^{\mathrm{d}}$} \\
\hline & Barrow & Gilt & Barrow & Gilt & & $\mathrm{T}$ & $S$ & $\mathrm{~T} \times \mathrm{S}$ \\
\hline Initial wt (kg) & 64.2 & 63.3 & 63.3 & 65.5 & 1.68 & 0.821 & 0.824 & 0.612 \\
\hline Final wt (kg) & 94.9 & 95.7 & 98.6 & 98.2 & 1.96 & 0.445 & 0.960 & 0.891 \\
\hline \multicolumn{9}{|c|}{ Average daily gain (g) } \\
\hline Wk 1 & 970.4 & 1370.1 & 1324.5 & 1048.8 & 143.2 & 0.932 & 0.753 & 0.095 \\
\hline Wk 2 & 1299.8 & 1179.4 & 1584.1 & 1437.2 & 60.9 & 0.020 & 0.226 & 0.900 \\
\hline Wk 3 & 1090.0 & 1110.8 & 1113.5 & 1097.4 & 48.6 & 0.950 & 0.977 & 0.818 \\
\hline Wk 4 & 1032.1 & 968.9 & 1020.4 & 1084.6 & 41.1 & 0.496 & 0.995 & 0.406 \\
\hline Wk 1 to 4 & 1098.1 & 1157.3 & 1260.6 & 1167.0 & 27.1 & 0.044 & 0.739 & 0.085 \\
\hline \multicolumn{9}{|c|}{ Average daily feed intake (kg) } \\
\hline Wk 1 & 2.48 & 2.38 & 2.45 & 2.36 & 0.08 & 0.816 & 0.461 & 0.937 \\
\hline Wk 2 & 2.85 & 2.77 & 3.02 & 2.79 & 0.10 & 0.541 & 0.339 & 0.634 \\
\hline Wk 3 & 3.12 & 2.91 & $3.36^{\mathrm{e}}$ & 2.75 & 0.09 & 0.042 & 0.025 & 0.236 \\
\hline Wk 4 & 3.01 & 2.73 & 3.12 & 2.96 & 0.10 & 0.336 & 0.217 & 0.724 \\
\hline Wk 1 to 4 & 2.87 & 2.70 & 2.98 & 2.71 & 0.07 & 0.601 & 0.105 & 0.690 \\
\hline \multicolumn{9}{|l|}{ Gain:feed ratio } \\
\hline Wk 1 & 0.41 & 0.61 & 0.55 & 0.49 & 0.07 & 0.863 & 0.378 & 0.091 \\
\hline Wk 2 & 0.47 & 0.44 & 0.54 & 0.53 & 0.03 & 0.085 & 0.676 & 0.795 \\
\hline Wk 3 & 0.35 & 0.38 & 0.33 & 0.40 & 0.01 & 0.850 & 0.021 & 0.390 \\
\hline Wk 4 & 0.34 & 0.36 & 0.33 & 0.37 & 0.01 & 0.984 & 0.180 & 0.507 \\
\hline Wk 1 to 4 & 0.39 & 0.43 & 0.42 & 0.43 & 0.01 & 0.093 & 0.052 & 0.158 \\
\hline
\end{tabular}

${ }^{a}$ Values are means of five pens containing five pigs each.

b Diet contained $0.05 \%$ carbohydrase supplementation.

c Pooled standard error of the means.

${ }^{\mathrm{d}} P$ values for difference between the treatments $(\mathrm{T})$, between the sexes $(\mathrm{S})$, and interaction $(\mathrm{T} \times \mathrm{S})$ of the treatment and the sex.

\section{DISCUSSION}

These experiments indicate that it is beneficial to add a CS supplement containing $\alpha$-1,6-galactosidase, $\beta$-1,4-mannanase, and $\beta$-1,4-mannosidase to diets of grower and finisher pigs. Apparent ileal digestibilities of dietary GE and amino acids in soybean meal were improved by about $3 \%$ by the addition of CS. Supplementing $0.05 \%$ CS allowed growing and finishing pigs fed a lower energy diet (97 or $95 \%$ of the $\mathrm{ME}$ in the control diet) to achieve perfor- mance equal to pigs fed the higher energy control diet without increasing voluntary feed intake under ad libitum feeding condition. Collectively, these experiments indicate that dietary CS supplementation can improve energy utilization in grower and finisher diets and may reduce aerial ammonia concentration from pig manure.

The improvements in digestibility found in Exp. 1 were obtained in corn starch based diets containing $35 \%$ soybean meal. In Exp. 2 and 3, soybean meal contents were $27 \%$ and $20 \%$ respectively. Assuming 


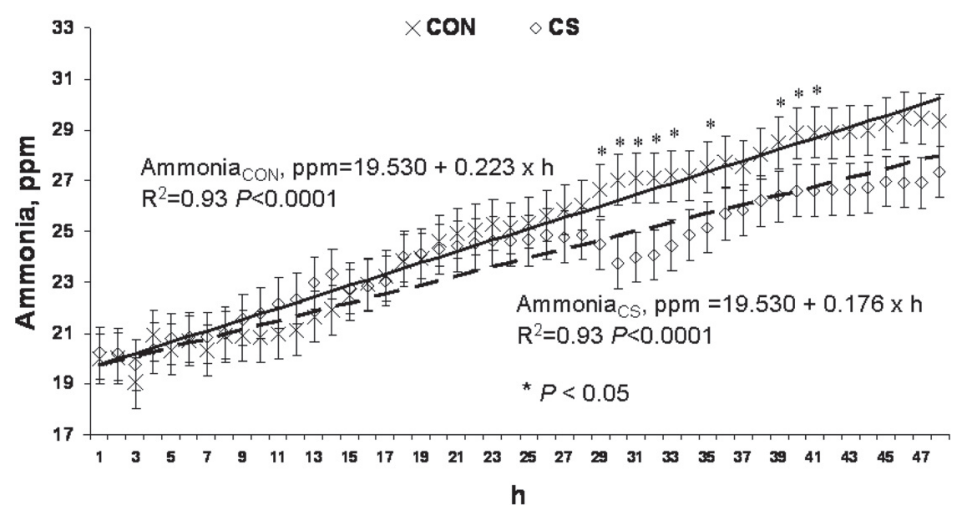

Figure 1. Aerial ammonia changes from pig excreta as affected by carbohydrase supplement during the $48 \mathrm{~h}$ collection period after the $18 \mathrm{~h}$ adjustment period. The control group: CON; and the carbohydrase supplemented group: CS.

Table IX. Effect of carbohydrase supplementation on aerial ammonia concentration from pig excreta (Exp. 4) .

\begin{tabular}{lccc}
\hline & Control & Carbohydrases $^{\mathrm{b}}$ & SEM $^{\mathrm{c}}$ \\
\hline Initial weight & & & \\
of pigs & 23.35 & 23.67 & 0.49 \\
ADG (g per d) & 560.6 & 560.8 & 3.9 \\
ADFI (g per d) & 1020.5 & 1052.9 & 2.1 \\
Ammonia (ppm) & & & \\
$0-48 \mathrm{~h}$ & 24.75 & 24.07 & 0.29 \\
$18-48 \mathrm{~h}$ (last 30 h) & $27.18^{\mathrm{d}}$ & $25.39^{\mathrm{e}}$ & 0.40 \\
$28-48 \mathrm{~h}$ (last 20 h) & $28.18^{\mathrm{f}}$ & $25.80^{\mathrm{g}}$ & 0.42 \\
$38-48 \mathrm{~h}$ (last 10 h) & 29.05 & 26.77 & 0.92 \\
\hline
\end{tabular}

${ }^{a}$ Values are means of three pens containing ten pigs each.

b Diet contained $0.05 \%$ carbohydrase supplementation.

${ }^{c}$ Pooled standard error of the means.

d,e Within a row, means without a common superscript letter tend to differ $(P<0.07)$.

f,g Within a row, means without a common superscript letter differ $(P<0.05)$.

that the same improvements occur in corn - wheat bran based diets, the predicted amount of additionally available gross energy and amino acids due to the CS sup- plement would be at least 2.3 and $3.1 \%$ respectively for Exp. 2 and 1.7 and $2.3 \%$ respectively for Exp. 3. These estimated improvements would be greater if CS supplement increased digestibility of flatulence producing compounds in corn.

Grower and finisher pigs fed the lowerenergy diet containing $0.05 \%$ CS performed as good as or better than pigs fed the higher energy control diet suggesting that CS may have improved nutrient utilization and performance. This assumption is valid only if there is adequate replication to detect true differences between treatments. Based on the formula provided by Martin et al. [14], 10 replications (the number of replications used in these experiments) should detect a difference of about $10 \%$ with a $P$ value (alpha) at 0.10 and power (1-beta) at 80 when the average coefficient of variation is $9 \%$ from most of the observations of this study. The $P$ values for ADG, ADFI, and gain:feed determined for the entire experiments were the following: $0.81,0.61,0.57$ for Exp. 2 indicating that there were no differences between the control and the CS groups. These large $P$ values suggest that lack of a negative control diet (i.e., a low energy diet without the CS supplement) in Exp. 2 does 
not invalidate the conclusions. However, the CS group performed even better than the control group in Exp. 3 which provided $P$ values of $0.04,0.60$, and 0.04 for ADG, ADFI, and gain:feed, respectively. Better performances by the low-energy CS group than the control also suggest that lack of a negative control diet in Exp. 3 does not invalidate the conclusions.

It has been shown that lysine:ME ratio affects voluntary feed intake of pigs. As pigs receive diets with increased lysine:ME ratios, their voluntary feed intake can also increase [20,27]. The CS diets used in this study had 5 and $3 \%$ higher lysine:ME ratios than the control diets for Exp. 2 and 3, respectively. However, these differences did not affect the voluntary feed intake of growing and finishing pigs during the 4 week feeding periods. Increased energy utilization $(2.8 \%)$ by the CS supplementation to low energy diets may reduce the difference with the control.

The CS supplement was composed of several enzymes including $\alpha$-1,6galactosidase, $\beta$-1,4-mannanase, and $\beta$-1,4-mannosidase. The improvement in digestibility and growth may be due to successful degradation of flatulence producing compounds in the GIT [12]. Early studies indicate that the supplementation of a single enzyme targeting only a part of flatulence producing compounds did not improve digestibility [25]. This may be due to incomplete digestion of flatulence producing compounds in the feed. All three enzymes are required for the complete digestion of $\beta$-galactomannans $[18,19]$ indicating that the complete digestion of $\beta$-galactomannans, as an example of flatulence producing compounds, requires all three enzymes including $\alpha$-1,6-galactosidase, $\quad \beta$-1,4-mannanase, and $\beta$-1,4-mannosidase.

It can be argued that the flatulence producing compounds may provide some benefit to pigs due to the volatile fatty acids (VFA) produced from their fermen- tation by microorganisms in the GIT. Kass et al. [10] demonstrated that microbial fermentation can provide up to $12 \%$ of ME required by pigs weighing $90 \mathrm{~kg}$ when they were fed a diet with up to $60 \%$ alfalfa meal. The results of Exp. 2 and 3 suggest that increased digestion of flatulence producing compounds in the foregut, due to CS addition, outweighs the possible benefit from VFA production in the hindgut. However, the actual amount of VFA production was not measured in this study.

Standardized ileal digestibility of nutrients was measured by considering endogenous losses of nutrients as described [6]. The amounts of endogenous amino acids from finisher pigs were numerically lower $(8 \%)$ than those obtained by Stein et al. [21], even though body weights of pigs were similar between the current study (93.9 kg) and Stein et al. [21] $(111.7 \mathrm{~kg})$. However, the diets used for the measuring endogenous loss were different. Stein et al. [21] used a proteinfree diet whereas the current study used a low-protein diet containing 5\% casein. Fan et al. [6] demonstrated that the amount of endogenous amino acid or protein loss decreases as dietary protein content increases indicating the use of protein-free diet to measure the amount of endogenous amino acid loss may cause overestimation.

Standardized ileal digestibility of amino acids in soybean meal was the same between the control group of the current study and Stein et al. [22] indicating the validity of digestibility coefficients obtained from the current study. Addition of the carbohydrase supplement $(0.05 \%)$ improved $(P<0.05)$ standardized ideal amino acid digestibility of soybean meal by $3.3 \%$.

The CS supplement reduced the rate of increase in ammonia emission from the pig's manure and reduced the average ammonia concentration during the last $20 \mathrm{~h}$ collection period in Exp. 4 even though the average values of the entire $48 \mathrm{~h}$ collection period were not different indicating 
that an extended period of ammonia collection may increase the differences in average aerial ammonia concentrations. This result may imply that the utilization of dietary protein by pigs was improved or excretion of pigs' body protein was reduced. Based on the results from Exp. 1, 2 , and 3 , the decreased rate of aerial ammonia emission can be explained by improved amino acid digestibility and growth performance. It can be argued that the improved amino acid digestibility may increase amino acid oxidation and therefore increase nitrogen excretion through urine if those absorbed amino acids are not efficiently used for tissue synthesis. In this study, nitrogen content in urine was not measured to answer this possible argument. However, the CS supplements not only increased the amount of dietary amino acid available as shown in Exp. 1, but also benefited the tissue gain of pigs as shown in Exp. 2 and 3 suggesting that the total amount of nitrogen excreted through urine and feces may be reduced as indicated by the reduced increase of ammonia emission. Reduced microbial activity may also help to reduce ammonia emission by decreasing urease activity. Microorganisms in GIT secrete urease that will break down urea into free ammonia [1]. Reduced microbial activity may reduce urease secretion which, in turn, reduces ammonia emission from pigs' manure. The results from the current study are supported by Canh et al. [4] and Mroz et al. [15] who measured ammonia emission from the manure of pigs fed diets with nonstarch polysaccharide (NSP) supplementation. Both studies indicated that in vitro ammonia emission per $\mathrm{kg}$ of manure is reduced by dietary NSP supplementation. However, considering the amount of manure produced, the total ammonia produced from the pigs fed diets with NSP supplementation were between 65 and $118 \%$ more, depending on NSP sources, than that from the pigs fed the control diets indicating dietary NSP ac- tually increased total ammonia production from the pig manure.

\section{ACKNOWLEDGEMENTS}

The authors wish to acknowledge the financial support from the EasyBio System, Inc. Seoul, Korea

\section{REFERENCES}

[1] Aarnick A.J.A., Hoeksma P., van Ouwerkerk E.N.J., Factors affecting ammonia concentration in slurry from fattening pigs, in: Verstegen M.W.A., den Hartog L.A., van Kepen G.J.M., Metz J.H.M. (Eds.), Proceedings of the Congress on Nitrogen Flow in Pig Production and Environmental Consequences, Pudoc, Wageningen, The Netherlands, 1993, pp. 413-420.

[2] AOAC, Official Methods of Analysis, 16th ed., Association of Official Analytical Chemists, Washington, DC, 1995.

[3] Baucells F., Perez J.F., Morales J., Gasa J., Effect of $\forall$-galactosidase supplementation of cereal-soya-been-pea diets on the productive performances, digestibility and lower gut fermentation in growing and finishing pigs, Anim. Sci. 71 (2000) 157-164.

[4] Canh T.T., Sutton A.L., Aarnink A.J.A., Verstegen M.W.A., Schrama J.W., Bakker G.C.M., Dietary carbohydrates alter the fecal composition and $\mathrm{pH}$ and the ammonia emission from slurry of growing pigs, J. Anim. Sci. 76 (1998) 1887-1895.

[5] Chung T.K., Baker D.H., Apparent and true amino acid digestibility of a crystalline amino acid mixture and of casein: Comparison of values obtained with ileal-cannulated pigs and cecectomized cockerels, J. Anim. Sci. 70 (1992) 37813790.

[6] Fan M.Z., Sauer W.C., McBurney M.I., Estimation by regression analysis of endogenous amino acid levels in digesta collected from the distal ileum of pigs, J. Anim. Sci. 73 (1995) 2319-2328.

[7] Gdala G., Jansman A.J.M., Buraczewska L., Huisman J., van Leeuwen P., The influence of $\forall$-galactosidase supplementation on the 
ileal digestibility of lupin seed carbohydrates and dietary protein in young pigs, Anim. Feed Sci. Tech. 67 (1997) 115-125.

[8] Gitzelman P., Auricchio S., The handling of alpha-galactosidase by a normal galactosemic child, Pediatric. 36 (1965) 231-232.

[9] Karr-Lilienthal L.K., Merchen N.R., Grieshop C.M., Flahaven M.A., Mahan D.C., Fastinger N.D., Watts M., Fahey G.C. Jr., Ileal amino acid digestibilities by pigs fed soybean meals from five major soybean-producing countries, J. Anim. Sci. 82 (2004) 3198-3209.

[10] Kass M.L., Van Soest P.J., Pond W.G., Utilization of dietary fiber from alfalfa by growing swine. II. Volatile fatty acid concentrations in and disappearance from the gastrointestinal tract, J. Anim. Sci. 50 (1980) 192-197.

[11] Kim S.W., Easter R.A., Evaluation of various fish meals as a protein source in young pig diets, J. Anim. Sci. 79 (2001) 1829-1839.

[12] Kim S.W., Knabe D.L., Hong K.J., Easter R.A., Use of carbohydrases in corn-soybean meal-based nursery diets, J. Anim. Sci. 81 (2003) 2496-2504.

[13] Liener I.E., Non-nutritive factors and bioactive compounds in soy, in: Drackley J.K. (Ed.), Soy in Animal Nutrition, Federation of Animal Science Societies, Savoy, IL, 2000, pp. 13-34.

[14] Martin S.W., Meek A.H., Willeberg P., Veterinary Epidemiology: Principles and Methods, Iowa State University Press, Ames, Iowa, 1987.

[15] Mroz Z., Moeser A.J., Vreman K., van Diepen J.T.M., van Kempen T., Canh T.T., Jongbloed A.W., Effects of dietary carbohydrates and buffering capacity on nutrient digestibility and manure characteristics in finishing pigs, J. Anim. Sci. 78 (2000) 3096-3106.

[16] Nielsen H.K., Hurrell R.F., Tryptophan determination of food proteins by HPLC after alkaline hydrolysis, J. Sci. Food Agr. 36 (1985) 893-907.

[17] NRC, Nutritional Requirements of Pigs, 10th ed. Natl Acad. Press, Washington, DC, 1998.

[18] Reid J.S.G., Galactomannans, in: Dey P.M., Dixon R.A. (Eds.), Biochemistry of Storage Carbohydrates in Green Plants, Academic Press, London, UK, 1985, pp. 265-284.
[19] Reid J.S.G., Edwards M.E., Galactomannans and other cell wall storage polysaccharides in seeds, in: Alistair M.S. (Ed.), Food Polysaccharides and Their Applications, Marcel Pekker, Inc., New York, 1995, pp. 155-186.

[20] Smith J.W., Tokach M.D., O’Quinn P.R., Nelssen J.L. Goodband R.D., Effects of dietary energy density and lysine:calorie ratio on growth performance and carcass characteristics of growing-finishing pigs, J. Anim. Sci. 77 (1999) 3007-3015.

[21] Stein H.H., Trottier N.L., Bellaver C., Easter R.A., The effect of feeding level and physiological status on total flow and amino acid composition of endogenous protein at the distal ileum in swine, J. Anim. Sci. 77 (1999) 1180-1187.

[22] Stein H.H., Kim S.W., Nielsen T.T., Easter R.A., Standardized ileal protein and amino acid digestibility by growing pigs and sows, J. Anim. Sci. 79 (2001) 2113-2122.

[23] Traylor S.L., Cromwell G.L., Lindemann M.D., Knabe D.A., Effects of level of supplemental phytase on ileal digestibility of amino acids, calcium, and phosphorus in dehulled soybean meal for growing pigs, J. Anim. Sci. 79 (2001) 2634-2642.

[24] van Kempen T.A.T.G., Kim I.B., Jansman A.J.M., Verstegen M.W.A., Hancock J.D., Lee D.J., Gabert V.M., Albin D.M., Fahey Jr. G.C., Grieshop C.M., Mahan D., Regional and processor variation in the ileal digestible amino acid content of soybean meals measured in growing swine, J. Anim. Sci. 80 (2002) 429-439.

[25] Veldman A.V., Veen W.A.G., Barug D., van Paridon P.A., Effect of $\forall$-galactosidase in feed on ileal piglet digestive physiology, J. Anim. Physiol. An. N. 69 (1993) 67-65.

[26] Wiggins H.S., Nutritional value of sugars and related compounds undigested in the small gut, Proc. Nutr. Soc. 43 (1984) 69-85.

[27] William N.H., Cline T.R., Schinckel A.P., Jones D.J., The impact of ractopamine, energy intake, and dietary fat on finisher growth performance and carcass merit, J. Anim. Sci. 72 (1994) 3152-3162.

[28] Williams C.H., David D.J., Iismaa O., The determination of chromic oxide in faeces samples by atomic absorption spectrophotometry, J. Agr. Sci. 59 (1962) 381-385. 